\title{
Phytic Acid Enhances Biocontrol Activity of Rhodotorula mucilaginosa against Penicillium expansum Contamination and Patulin Production in Apples
}

\author{
Qiya Yang, Hongyin Zhang*, Xiaoyun Zhang, Xiangfeng Zheng and Jingya Qian \\ School of Food and Biological Engineering, Jiangsu University, Zhenjiang, China
}

\section{OPEN ACCESS}

Edited by:

Sahdeo Prasad,

The University of Texas MD Anderson

Cancer Center, USA

Reviewed by:

Zuzana Hruska,

Mississippi State University, USA

Suni Tang,

Texas Tech University Health

Sciences Center, USA

Boqiang $\mathrm{Li}$,

Chinese Academy of Sciences, China

*Correspondence:

Hongyin Zhang

zhanghongyin126@126.com

Specialty section:

This article was submitted to

Food Microbiology,

a section of the journal

Frontiers in Microbiology

Received: 08 September 2015 Accepted: 06 November 2015

Published: 23 November 2015

Citation:

Yang $Q$, Zhang $H$, Zhang X, Zheng X and Qian J (2015) Phytic Acid

Enhances Biocontrol Activity of Rhodotorula mucilaginosa against Penicillium expansum Contamination and Patulin Production in Apples. Front. Microbiol. 6:1296. doi: 10.3389/fmicb.2015.01296
The effect of Rhodotorula mucilaginosa in combination with phytic acid (PA) on blue mold decay and patulin contamination of apples was investigated. Results from this study show that different concentrations of PA were effective in reducing the disease incidence of apples and that PA at concentration of $4 \mu \mathrm{mol} / \mathrm{mL}$, decreased the incidence of blue mold decay in apples from 86.1 to $62.5 \%$, and showed higher control efficacy compared to untreated, control fruit during storage at $20^{\circ} \mathrm{C}$. However, R. mucilaginosa combined with PA (4 $\mu \mathrm{mol} / \mathrm{mL})$ showed better control efficacy of blue mold decay than $R$. mucilaginosa used as single treatment, the disease incidence was reduced to $62.5 \%$ and lesion diameter on apples was reduced to $16.59 \mathrm{~cm}$. In in vitro experiments, the addition of PA enhanced the biocontrol effect of $R$. mucilaginosa against the growth of Penicillium expansum and reduced patulin level when compared with either $R$. mucilaginosa or PA used separately. R. mucilaginosa together with PA, improved the inhibition of patulin production in wounded apples, decreasing the content of patulin by 89.6\% compared to the control, under experimental conditions. Both R. mucilaginosa and $R$. mucilaginosa in combination with PA degraded patulin in vitro. In conclusion, the appropriate combination of $R$. mucilaginosa and PA may provide an effective biocontrol method for reducing postharvest decay of apples.

Keywords: phytic acid (PA), Rhodotorula mucilaginosa, biocontrol, Penicillium expansum, apples, patulin

\section{INTRODUCTION}

Patulin (PAT) is a mycotoxin produced by Penicillium (P.), Aspergillus (A.), and Byssochlamys species. Among these fungi, Penicillium expansum is the most important producer of the mycotoxin that can be detected in fruits and fruit juices (Sommer et al., 1974; Paster et al., 1995). $P$. expansum, which often develops on the surface of healthy fruit, is the predominant postharvest fungus in apples. $P$. expansum produces PAT that is normally associated with fruits infected by microorganisms in postharvest conditions (Riteni, 2003).

The control of diseases in postharvest fruit is based on the use of chemical fungicides, but the progressive loss of their effectiveness and the emergence of resistant pathogens are major concerns, due to the increasing levels of agro-toxic residues (Sugar and Spotts, 1999; Castoria et al., 2001). The need for exploration of alternatives to synthetic fungicides has attracted attention because intensive use of synthetic chemical fungicides may give rise to a number of toxicological problems 
regarding human safety and effects on the environment (Droby, 2006). Biological control using antagonistic microorganisms is a promising alternative that provides a safe application method for both human health and the ecosystem (Janisiewicz et al., 2000; Usall et al., 2001). The phylloplane yeast Rhodotorula mucilaginosa has been reported to control Botrytis cinerea on geranium seedlings in combination with fungicides (Buck, 2004). We previously found that $R$. mucilaginosa has biocontrol efficacy against blue mold in apples caused by $P$. expansum (Li et al., 2011). Recently we discovered the efficacy of Pichia caribbica in controlling postharvest blue mold in apples and degrading the patulin produced by $P$. expansum (Cao et al., 2013).

Alternatives to chemical control, particularly biological control, are often less effective than many of the commercial fungicides currently in use. Therefore, the efficacy of antagonistic yeasts in controlling postharvest diseases need to be enhanced (Janisiewicz and Korsten, 2002). Substances (organic and inorganic additives) have been applied in combination with biocontrol agents for a synergistic effect (Janisiewicz, 1994; ElGhaouth et al., 2000).

Phytic acid is a simple ringed carbohydrate with six phosphate groups attached to each carbon. In the plant kingdom PA is the principal storage form of phosphorus, particularly abundant in cereals and legumes (Shamsuddin, 2002). It may provide some health benefits to the human body, however, it is commonly defined as an antinutrient to humans and nonruminant animals that reduces the availability of nutrients and decreases the absorption of micronutrients (Brankovic et al., 2015; Burgos-Lujan and Tong, 2015). PA is a naturally occurring compound that is non-toxin, biocompatible, and green to the environment (Gupta et al., 2013). Moreover, Du et al. (2012) found that apple juice treated with phytic acid had significantly lower browning formation during processing and subsequent 6 months of storage at room temperature, compared with the control. Similarly, we have found that the combination of R. mucilaginosa and PA at the concentration of $4 \mu \mathrm{mol} / \mathrm{mL}$ was the most effective treatment in controlling the natural spoilage of strawberries after storage at $4{ }^{\circ} \mathrm{C}$ for 20 days followed by $20^{\circ} \mathrm{C}$ for 5 days (Zhang et al., 2013). However, to our knowledge, there is no information concerning the effects of a combination of antagonistic yeast and PA on the control of the postharvest blue mold decay and patulin production in apples.

The objectives of this study were to evaluate the effects of $\mathrm{PA}, R$. mucilaginosa treatment alone or in combination with PA in controlling postharvest blue mold decay, mycelial growth of $P$. expansum, patulin production by $P$. expansum in NYDB media, the degradation of patulin, and in the production of patulin by $P$. expansum in apples.

\section{MATERIALS AND METHODS}

\section{Pathogen Inocula}

Penicillium expansum (preserved in the China General Microbiological Culture Collection Center, No.3.3703) was isolated from infected apples. The culture was maintained on potato dextrose agar media (PDA: extract of boiled potatoes, $200 \mathrm{~g}$; glucose, $20 \mathrm{~g}$; agar, $20 \mathrm{~g}$ and distilled water, $1000 \mathrm{~mL}$ ) at $4^{\circ} \mathrm{C}$. Fresh cultures were grown on PDA plates at $28^{\circ} \mathrm{C}$ before use. Spore suspensions were prepared by removing the spores from the sporulating edges of a 7-day-old culture with a bacteriological loop, and then suspending them in sterile distilled water. Suspensions were filtered through four layers of cheesecloth to remove fungal mycelia and spore concentrations were determined with a hemocytometer, with the concentration adjusted as required by adding sterile distilled water.

\section{Antagonist Isolation}

The yeast antagonist $R$. mucilaginosa (preserved in the China General Microbiological Culture Collection Center, No.3617) was isolated from the surfaces of peach blossoms picked in unsprayed orchards. Subsequently, sequence analysis of the $5.8 \mathrm{~S}$ internal transcribed spacer (ITS) ribosomal DNA (rDNA) region was used to identify the yeast. $R$. mucilaginosa has been shown to be safe in animal testing, including physiology experiments, acute toxicity studies, and the Ames test (our unpublished data). $R$. mucilaginosa isolates were maintained at $4^{\circ} \mathrm{C}$ on nutrient yeast dextrose agar (NYDA) medium containing $8 \mathrm{~g}$ nutrient broth, $5 \mathrm{~g}$ yeast extract, $10 \mathrm{~g}$ glucose, and $20 \mathrm{~g}$ agar (Sangon Co., Shanghai, China), in $1 \mathrm{~L}$ of distilled water. Liquid cultures of the yeast were grown in $250 \mathrm{~mL}$ Erlenmeyer flasks containing $50 \mathrm{~mL}$ of NYD broth (NYDB) that had been inoculated with a loop of the culture. Flasks were incubated on a rotary shaker at $28^{\circ} \mathrm{C}$ for $20 \mathrm{~h}$. Following incubation, the cells were centrifuged (TGL-16M Centrifuge, Xiangyi Co., Changsha, China) at $7000 \mathrm{~g}$ for $10 \mathrm{~min}$ and washed twice with sterile distilled water in order to remove the growth medium. Yeast cell pellets were re-suspended in sterile distilled water and adjusted to an initial concentration of $2-5 \times 10^{9}$ cells $/ \mathrm{mL}$ before being adjusted to the concentrations required for the different experiments.

\section{Fruit Samples}

Apples (Malus domestica Borkh, cv. Fuji) were harvested at commercial maturity from an orchard in Yantai, Shandong province, and selected for uniformity of size, ripeness, and the absence of apparent injury or infection. Fruit was selected randomly and disinfected with $0.1 \%$ sodium hypochlorite for $1 \mathrm{~min}$, washed with tap water and allowed to air dry at room temperature $\left(20^{\circ} \mathrm{C}\right)$.

\section{Effects of PA at Various Concentrations of Blue Mold Decay of Apples}

The apples were wounded ( $3 \mathrm{~mm}$ diameter and approximately $3 \mathrm{~mm}$ deep) using a sterile borer. Each wound was treated with $30 \mu \mathrm{L}$ of PA (Sangon Co., Shanghai, China) at 2, 4, 6,8 , or $10 \mu \mathrm{mol} / \mathrm{mL}$. Sterile distilled water was used as a control. Two hours later, $30 \mu \mathrm{L}$ of $P$. expansum suspension $\left(5 \times 10^{4}\right.$ spores $\left./ \mathrm{mL}\right)$ were inoculated into each wound. After air drying, the apples were stored in enclosed plastic 
trays to maintain a high relative humidity (about 95\%), and incubated at $20^{\circ} \mathrm{C}$. The percentage of infected fruit was recorded 10 days after inoculation. There were three replicates of 12 pieces of fruit, and the experiment was conducted twice.

\section{Effects of $R$. mucilaginosa in Combination with PA on Blue Mold Decay of Apples}

The surface of apples was wounded with a sterile cork borer (approximately 3-mm-diameter and 3-mm-deep). Each wound was treated with $30 \mu \mathrm{L}$ of different treatment solution as follows: (1) the cell suspensions of $R$. mucilaginosa alone $\left(1 \times 10^{8}\right.$ cells $\left./ \mathrm{mL}\right),(2)$ the cell suspensions of $R$. mucilaginosa $\left(1 \times 10^{8}\right.$ cells $\left./ \mathrm{mL}\right)$ supplemented with $\mathrm{PA}$ at the concentration of $2,4,6,8$, and $10 \mu \mathrm{mol} / \mathrm{mL}$, (3) sterile distilled water as a control. Two hours later, $30 \mu \mathrm{L}$ of $P$. expansum suspension $\left(5 \times 10^{4}\right.$ spores $\left./ \mathrm{mL}\right)$ was inoculated into each wound. After air drying, the samples were stored in enclosed plastic trays to maintain a high relative humidity (about 95\%) and incubated at $20^{\circ} \mathrm{C}$ in an incubator (Radford Technology Co., Ltd., Ningbo, China). The percentage of infected fruit and lesion diameter of the treated fruit were recorded 10 days after inoculation. There were three replicates of 12 pieces of fruit, and the experiment was conducted twice.

\section{Effects of $R$. mucilaginosa in Combination with PA on the Mycelial Growth of $P$. expansum}

The effects of PA on the mycelial growth of $P$. expansum was assayed in PDA media. 5-mm-diameter and 5-mm-deep disks were cut from potato-dextrose agar (PDA) plates and then $100 \mu \mathrm{L}$ of $1 \times 10^{8}$ cells $/ \mathrm{mL}$ of washed cell suspension of $R$. mucilaginosa, or $R$. mucilaginosa supplemented with PA at $4 \mu \mathrm{mol} / \mathrm{mL}$, or a solution of PA at $4 \mu \mathrm{mol} / \mathrm{mL}$, or sterile distilled water as a control, was added into each wound site on the PDA plates. After $2 \mathrm{~h}, 100 \mu \mathrm{L}$ of a $5 \times 10^{4}$ spores $/ \mathrm{mL}$ suspension of $P$. expansum was added into each wound. The plates were incubated at $28^{\circ} \mathrm{C}$ for seven d, after which the colony diameters of $P$. expansum were recorded. There were three replicates per treatment, and the experiments were repeated three times.

\section{HPLC Analysis of Patulin}

Patulin was analyzed as described by Cao et al. (2013). An Agilent Technologies 1100 series system equipped with a quaternary pump and variable wavelength detector (Switzerland) was used. The analytical column was from Zorbax, SB$\mathrm{C}_{18} 250 \mathrm{~mm} \times 4.6 \mathrm{~mm}, 5 \mu \mathrm{m}$ (US). The mobile phase consisted of acetonitrile/water $(10: 90 \mathrm{v} / \mathrm{v})$ with flow rate of $1.0 \mathrm{~mL} / \mathrm{min}$. The UV detection was performed at $276 \mathrm{~nm}$. The linear fit was: $y=46.379 x+2.0732$, Pearson's coefficient $\left(R^{2}\right)=0.9997$. The limit of quantification (LOQ) was $9.6 \mathrm{ng}$ $(0.48 \mu \mathrm{g} / \mathrm{mL})$, and the limit of detection (LOD) was $3.2 \mathrm{ng}$ $(0.16 \mu \mathrm{g} / \mathrm{mL})$, with signal/noise $(\mathrm{S} / \mathrm{N})$ ratios of 10.2 and
3 , respectively. The recoveries were in the range of 95.2$102.6 \%$.

\section{Effects of $R$. mucilaginosa in Combination with PA on Patulin Production by $P$. expansum in NYDB Media}

One milliliter of one of the following solutions was added into different Erlenmeyer flasks $(250 \mathrm{~mL})$, each containing $50 \mathrm{~mL}$ of NYDB: (1) the cell suspensions of $R$. mucilaginosa alone $\left(1 \times 10^{8}\right.$ cells $\left./ \mathrm{mL}\right)$; (2) PA solution $(4 \mu \mathrm{mol} / \mathrm{mL}) ;(3)$ the cell suspensions of $R$. mucilaginosa $\left(1 \times 10^{8}\right.$ cells $\left./ \mathrm{mL}\right)$ supplemented with PA at $4 \mu \mathrm{mol} / \mathrm{mL}$ and (4) sterile distilled water as a control. The flasks were then inoculated with $1 \mathrm{~mL}$ of $P$. expansum $\left(5 \times 10^{6}\right.$ spores $)$, and incubated at $28^{\circ} \mathrm{C}$ for $72 \mathrm{~h}$ with agitation $(180 \mathrm{rpm})$. Following incubation, cells were centrifuged at $7000 \mathrm{~g}$ for $10 \mathrm{~min}$, and the supernatant was considered to be an enriched sample.

Approximately $5.0 \mathrm{~g}$ of sample was added to $10 \mathrm{~mL}$ of water, and was extracted with $3 \times 25 \mathrm{~mL}$ of ethyl acetate by shaking vigorously for $1 \mathrm{~min}$ each time. The organic phases were combined and cleaned with $10 \mathrm{~mL}$ of $14 \mathrm{~g} / \mathrm{L}$ sodium carbonate solution by shaking for $10 \mathrm{~s}$. The phases were allowed to separate and the aqueous phase was immediately extracted with $10 \mathrm{~mL}$ of ethyl acetate by shaking for $1 \mathrm{~min}$. The combined organic phases were added to five drops of glacial acetic acid. The combined solutions were then evaporated to just dryness in a water bath at $40^{\circ} \mathrm{C}$. The residue was immediately dissolved in $1 \mathrm{~mL}$ of buffer solution, filter sterilized (Millipore, $0.45 \mu \mathrm{m}$ ) and $100 \mu \mathrm{L}$ of this solution was injected into the HPLC system to determine the patulin content (Wu et al., 2008).

\section{Effects of $R$. mucilaginosa in Combination with PA in the Patulin Content Produced by $P$. expansum in Apples}

The surface of apples was wounded with a sterile cork borer (approximately 3-mm-diameter and 3-mm-deep). Each wound was treated with $30 \mu \mathrm{L}$ of either (1) the cell suspensions of R. mucilaginosa alone $\left(1 \times 10^{8}\right.$ cells $\left./ \mathrm{mL}\right)$, (2) PA solution (4 $\mu \mathrm{mol} / \mathrm{mL}$ ), (3) the cell suspensions of $R$. mucilaginosa $\left(1 \times 10^{8}\right.$ cells $\left./ \mathrm{mL}\right)$ supplemented with $\mathrm{PA}$ at $4 \mu \mathrm{mol} / \mathrm{mL}$ or $(4)$ sterile distilled water as a control. Two hours later, $30 \mu \mathrm{L}$ of the $P$. expansum suspensions $\left(5 \times 10^{4}\right.$ cells $\left./ \mathrm{mL}\right)$ was inoculated into each wound. After air drying, the samples were stored in enclosed plastic trays to maintain a high relative humidity (about 95\%) and incubated at $20^{\circ} \mathrm{C}$ for 10 days. After extracting the wounded tissue and a $1 \mathrm{~cm}$ margin surrounding the wound using a sterile borer, followed by high-speed homogenization, the apple juice was considered an enriched sample. The sample was processed as described above to determine the patulin content. There were three replicates of 12 pieces of fruit, and the experiment was repeated twice. 


\section{Degradation of Patulin by R. mucilaginosa, Used Alone or in Combination with PA In Vitro}

One milliliter of one of the following solutions was added into different Erlenmeyer flasks $(250 \mathrm{~mL})$, each containing $50 \mathrm{~mL}$ of NYDB: (1) the cell suspensions of $R$. mucilaginosa alone $\left(1 \times 10^{8}\right.$ cells $\left./ \mathrm{mL}\right)$; $(2)$ the cell suspensions of $R$. mucilaginosa $\left(1 \times 10^{8}\right.$ cells $\left./ \mathrm{mL}\right)$ supplemented with PA at $4 \mu \mathrm{mol} / \mathrm{mL}$. To each flask was added $1 \mathrm{mg}$ patulin. The flasks were then incubated at $28^{\circ} \mathrm{C}$ for $24 \mathrm{~h}$ with agitation $(190 \mathrm{rpm})$. Following incubation, cells were centrifuged at $7000 \mathrm{~g}$ for $10 \mathrm{~min}$ and the supernatant was considered to be an enriched sample. The patulin content of the samples was determined as described above to test the effects of $R$. mucilaginosa in combination with PA.

\section{Effects of PA at Various Concentrations on Antagonistic Yeast}

The effects of PA on antagonistic yeast was assayed in NYDA media. $100 \mu \mathrm{L}$ of $1 \times 10^{4}$ cells/mL of washed cell suspension of R. mucilaginosa supplemented with PA at the concentration of 2, $4,6,8$, and $10 \mu \mathrm{mol} / \mathrm{mL}$, or cell suspension of $R$. mucilaginosa as a control, was added to the NYDA plates. The plates were incubated at $28^{\circ} \mathrm{C}$ for 2 days, after which the colonies of $R$. mucilaginosa were recorded. There were three replicates per treatment, and the experiments were repeated twice.

\section{Statistical Analyses}

The data were analyzed by analysis of variance (ANOVA) using the statistical program SPSS/PC version II.x, (SPSS Inc. Chicago, IL, USA), and the Duncan's multiple range test was used to separate the means. In addition, when two group of data were compared, the independent samples $t$-test was applied for means separation. The statistical significance was assessed at a level of 0.05 .

\section{RESULTS}

\section{Effects of PA at Various Concentrations on Blue Mold Decay of Apples}

Phytic acid, at various concentrations, significantly decreased the incidence of blue mold decay in apples caused by $P$. expansum $(P<0.05$; Figure 1). $P A$ at $4 \mu \mathrm{mol} / \mathrm{mL}$ had the best efficacy, and decreased the incidence of blue mold decay in apples from $86.1 \%$ (the control) to $62.5 \%$.

\section{Effects of $R$. mucilaginosa in Combination with PA on Blue Mold Decay of Apples}

Rhodotorula mucilaginosa as stand-alone treatment significantly reduced the disease incidence of blue mold decay of apples compared with the control after 10 days storage at $20^{\circ} \mathrm{C}(P<0.05$; Figure 2A). Similarly, $R$. mucilaginosa in combination with PA at all concentrations tested, $(2,4,6,8$, and $10 \mu \mathrm{mol} / \mathrm{mL})$ reduced

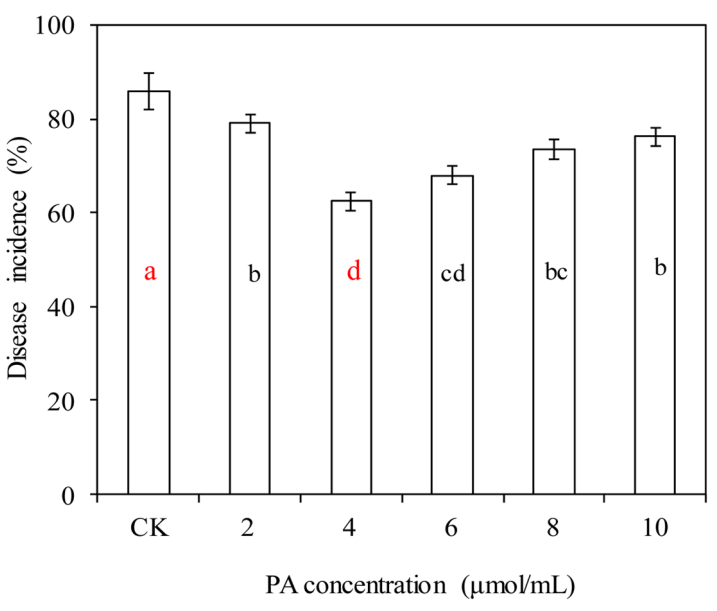

FIGURE 1 | Effects of phytic acid (PA) at various concentrations on blue mold decay of apples. Fruit treatments are as follows: $\mathrm{CK}=$ sterile distilled water, $(2,4,6,8,10)=\mathrm{PA}$ at different concentrations $(2,4,6,8$, and $10 \mu \mathrm{mol} / \mathrm{mL}$ ). Each value is the mean of two experiments. Bars represent standard deviations. Different letters indicate significant differences $(P<0.05)$ according to the Duncan's multiple range tests.

the disease incidence of blue mold decay of apples to 58.3, $19.4,44.4,50$, and $66.7 \%$, respectively. The lesion diameter of blue mold decay of the fruit treated with $R$. mucilaginosa in combination with PA at concentrations of 2, 4, and $10 \mu \mathrm{mol} / \mathrm{mL}$ was $17.1,16.6$, and $20.8 \mathrm{~cm}$, respectively, significantly reduced compared with the stand-alone $R$. mucilaginosa treatment $(26.2 \mathrm{~cm}$; Figure 2B). However, the combined treatments of R. mucilaginosa and $\mathrm{PA}$ at the concentration of $4 \mu \mathrm{mol} / \mathrm{mL}$ was most effective.

\section{Effects of $R$. mucilaginosa in Combination with PA on the Mycelial Growth of $P$. expansum}

On PDA plates, $4 \mu \mathrm{mol} / \mathrm{mL} \mathrm{PA}$, and $R$. mucilaginosaas as stand-alone treatments with diameters of 25.73 and $25.17 \mathrm{~cm}$, inhibited the growth of $P$. expansum, compared to the control (26.30 cm; Figure 3). However, the efficacy of the combined treatment of $R$. mucilaginosa and $4 \mu \mathrm{mol} / \mathrm{mL}$ PA with diameter of $24.21 \mathrm{~cm}$, was better than R. mucilaginosa or PA as stand-alone treatments.

\section{Effects of $R$. mucilaginosa in Combination with PA on Patulin Production by $P$. expansum in NYDB Media}

Phytic acid (4 $\mu \mathrm{mol} / \mathrm{mL})$ and $R$. mucilaginosa as standalone treatments significantly inhibited patulin production by $P$. expansum in NYDB media (Figures 4 and 5A-D). The concentration of patulin was 2.671 and $1.798 \mu \mathrm{g} / \mathrm{mL}$. However, $R$. mucilaginosa in combination with PA had greater inhibition on patulin production by $P$. expansum 


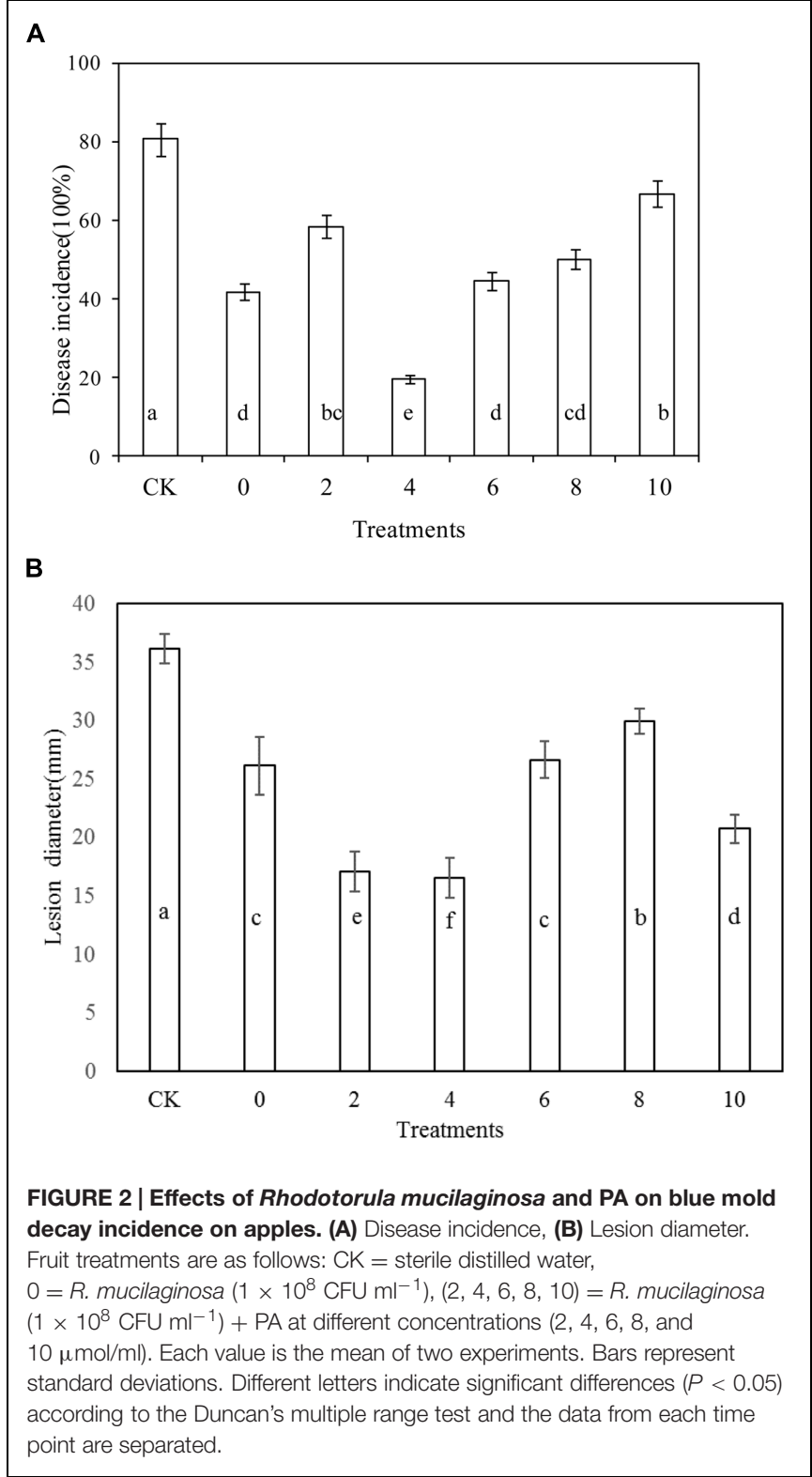

$(1.607 \mu \mathrm{g} / \mathrm{mL})$ than the $R$. mucilaginosa or PA treatments alone.

\section{Effects of R. mucilaginosa in Combination with PA on the Content of Patulin Produced by $P$. expansum in \\ Apples}

Phytic acid $(4 \mu \mathrm{mol} / \mathrm{mL})$ and $R$. mucilaginosa, used alone significantly decreased the content of patulin in apple wounds produced by $P$. expansumin by 6.9 and $76.8 \%$ respectively, compared to the control (Figures 5E-H and 6). However, $R$. mucilaginosa in combination with $\mathrm{PA}$, had even greater inhibition than PA and R. mucilaginosa used alone, decreasing the content of patulin by $89.6 \%$ compared to the control.

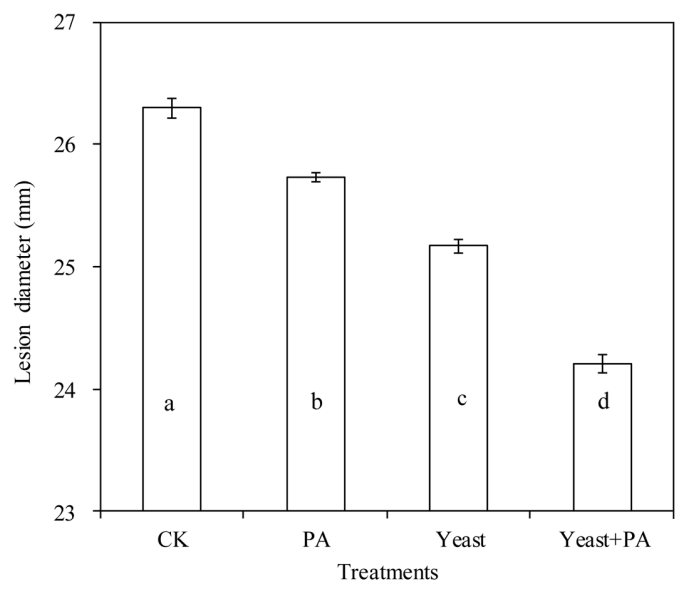

FIGURE 3 | Effects of $R$. mucilaginosa in combination with PA on mycelial growth of Penicillium expansum. Treatments are as follows: $\mathrm{CK}=$ sterile distilled water, $\mathrm{PA}=4 \mu \mathrm{mol} / \mathrm{mL} \mathrm{PA}$, yeast $=R$. mucilaginosa $\left(1 \times 10^{8} \mathrm{CFU} / \mathrm{mL}\right)$, yeast $+\mathrm{PA}=R$. mucilaginosa

$\left(1 \times 10^{8} \mathrm{CFU} / \mathrm{mL}\right)+4 \mu \mathrm{mol} / \mathrm{mL}$ PA. Each value is the mean of three experiments. Bars represent standard deviations. Different letters indicate significant differences $(P<0.05)$ according to the Duncan's multiple range test.

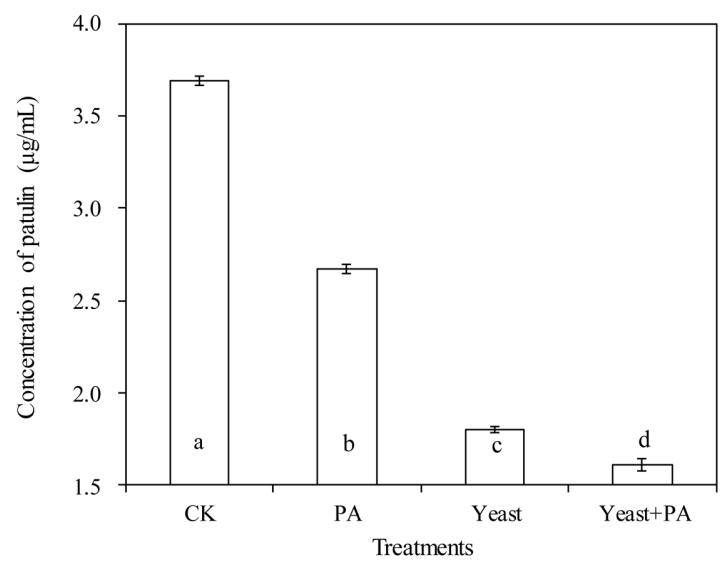

FIGURE 4 | Effects of $\boldsymbol{R}$. mucilaginosa in combination with PA on patulin content produced by $\boldsymbol{P}$ expansum in NYDB media. Treatments are as follows: $\mathrm{CK}=$ sterile distilled water, $\mathrm{PA}=4 \mu \mathrm{mol} / \mathrm{mL} \mathrm{PA}$, yeast $=R$. mucilaginosa $\left(1 \times 10^{8} \mathrm{CFU} / \mathrm{mL}\right)$, yeast $+\mathrm{PA}=R$. mucilaginosa $\left(1 \times 10^{8} \mathrm{CFU} / \mathrm{mL}\right)+4 \mu \mathrm{mol} / \mathrm{mL}$ PA. Each value is the mean of two experiments. Bars represent standard deviations. Different letters indicate significant differences $(P<0.05)$ according to the Duncan's multiple range test.

\section{Degradation of Patulin by}

\section{R. mucilaginosa, used Alone or in Combination with PA In Vitro}

The initial patulin concentration of $20 \mu \mathrm{g} / \mathrm{mL}$ in the presence of $R$. mucilaginosa cells was decreased over $92.11 \%$ after $24 \mathrm{~h}$ incubation at $28^{\circ} \mathrm{C}$; the final patulin concentration was $1.578 \mu \mathrm{g} / \mathrm{mL}$ (Table 1). Similarly, R. mucilaginosa in combination 
A

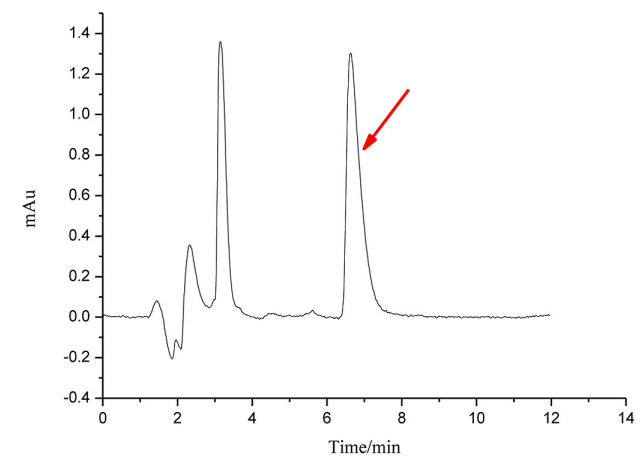

B

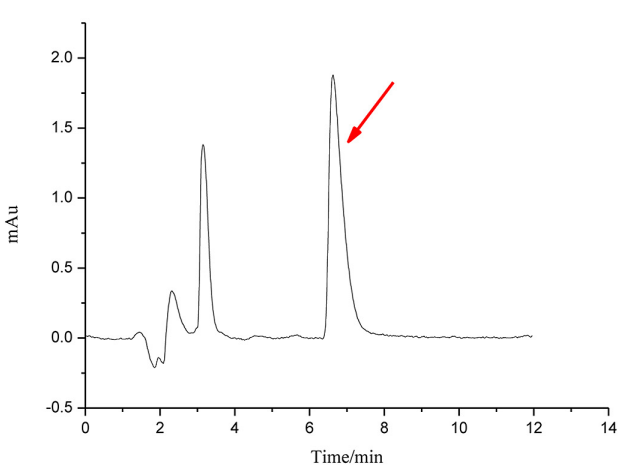

C

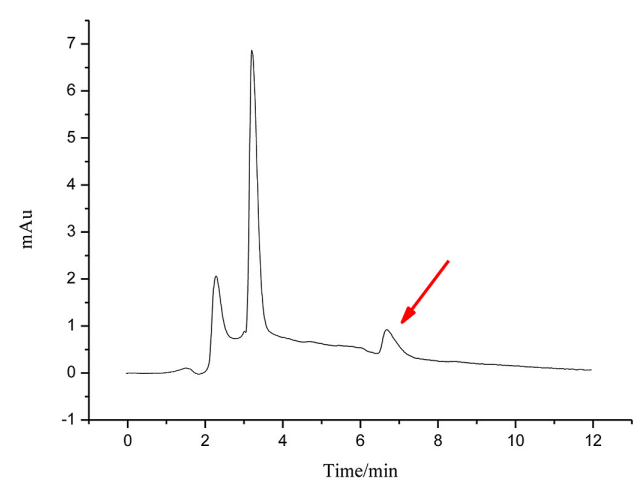

D

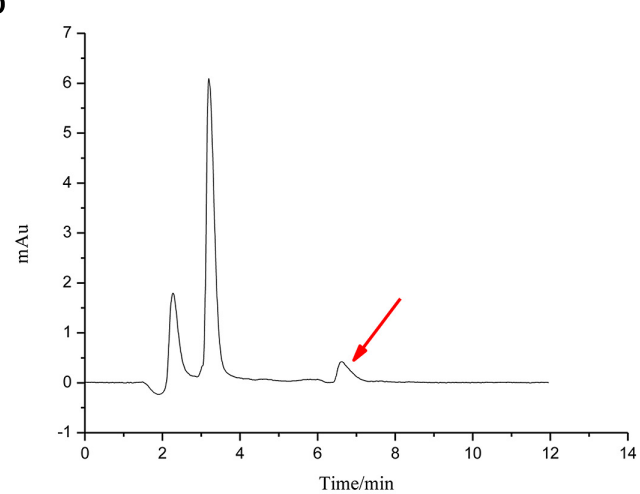

E

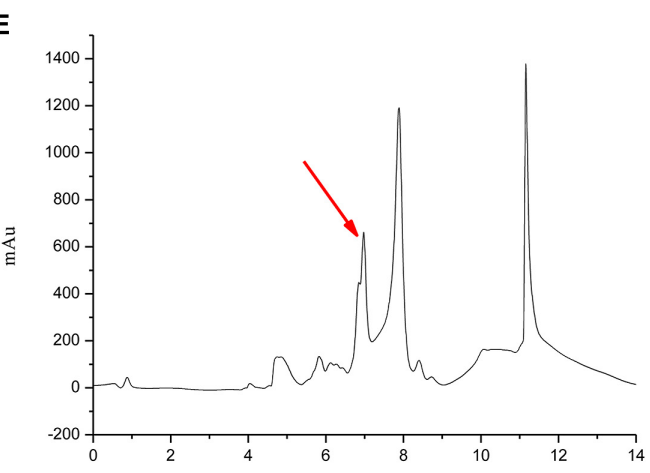

$\mathbf{F}$

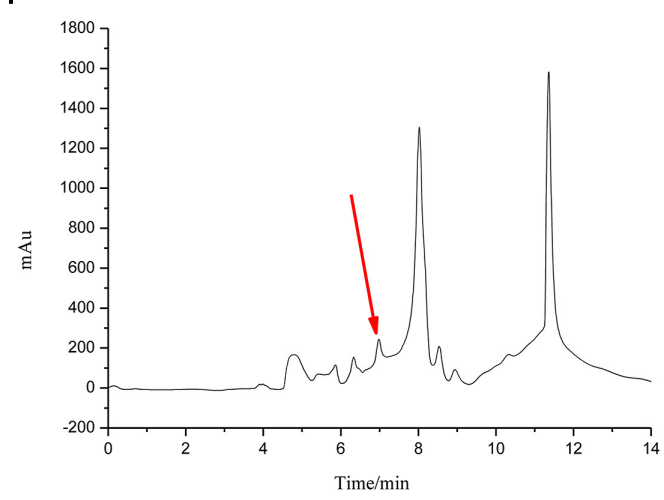

G

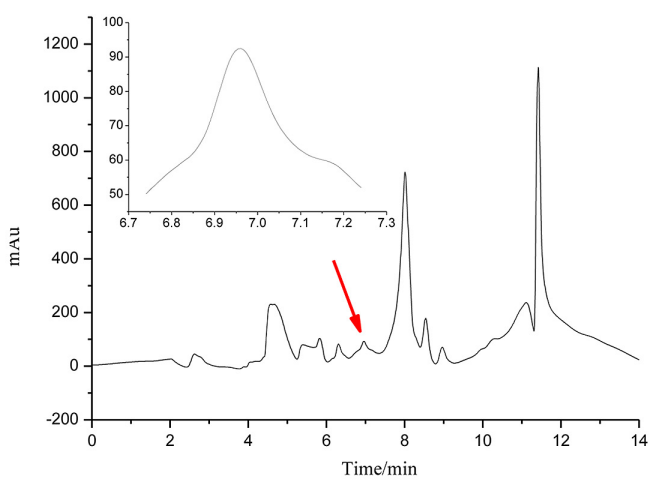

H

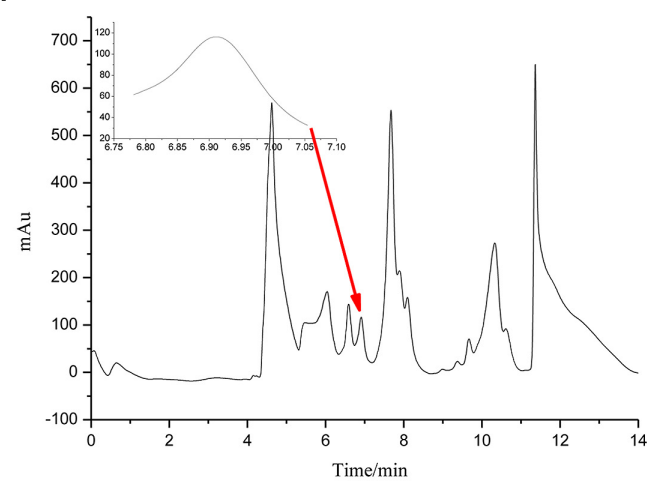

FIGURE 5 | Chromatograms for Figures 4 and 6. The chromatograms from (A-D) show the effects of $R$. mucilaginosa in combination with PA on patulin content produced by $P$. expansum in NYDB media. The chromatograms from $\mathbf{( E - H )}$ show the effects $R$. mucilaginosa in combination with PA on patulin content produced by $P$. expansum in apples. Treatments are as follows: $(\mathbf{A}), E=$ sterile distilled water, $(\mathbf{B}, \mathbf{F})=4 \mu \mathrm{mol} / \mathrm{mL}$ PA, $(\mathbf{C}, \mathbf{G})=$ R. mucilaginosa $\left(1 \times 10^{8} \mathrm{CFU} / \mathrm{mL}\right)$,

$\mathbf{( D , H )}=R$. mucilaginosa $\left(1 \times 10^{8} \mathrm{CFU} / \mathrm{mL}\right)+4 \mu \mathrm{mol} / \mathrm{mL}$ PA. 


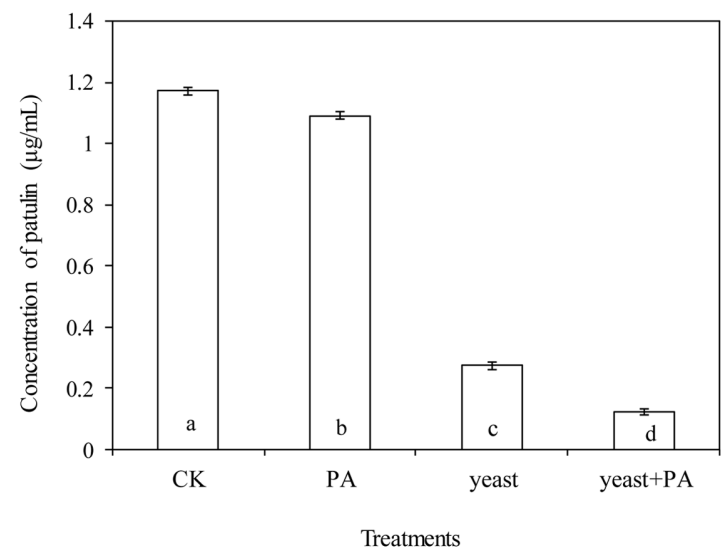

FIGURE 6 | Effects of $\boldsymbol{R}$. mucilaginosa in combination with PA on the patulin content produced by $\boldsymbol{P}$. expansum in apples. Fruit treatments are as follows: $\mathrm{CK}=$ sterile distilled water, $\mathrm{PA}=4 \mu \mathrm{mol} / \mathrm{mL} \mathrm{PA}$,

yeast $=R$. mucilaginosa $\left(1 \times 10^{8} \mathrm{CFU} / \mathrm{mL}\right)$, yeast $+\mathrm{PA}=R$. mucilaginosa $\left(1 \times 10^{8} \mathrm{CFU} / \mathrm{mL}\right)+4 \mu \mathrm{mol} / \mathrm{mL}$ PA. Bars represent standard deviations. Different letters indicate significant differences $(P<0.05)$ according to the Duncan's multiple range test.

TABLE 1 | The degradation of patulin by $R$. mucilaginosa, used alone or in combination with PA in vitro.

\begin{tabular}{|c|c|c|c|}
\hline Treatments & $\begin{array}{c}\text { Initial patulin } \\
\text { concentration } \\
(\mu \mathrm{g} / \mathrm{mL})\end{array}$ & $\begin{array}{c}\text { Final patulin } \\
\text { concentration } \\
(\mu \mathrm{g} / \mathrm{mL})\end{array}$ & $\begin{array}{l}\text { Degradation } \\
\text { rate }(\%)\end{array}$ \\
\hline$R$ mucilaginosa & 20 & 1.578 & 92.1 \\
\hline $\begin{array}{l}\text { R. mucilaginosa }+ \\
4 \mu \mathrm{mol} / \mathrm{mL} \mathrm{P}\end{array}$ & 20 & 1.561 & 92.2 \\
\hline
\end{tabular}

with PA $(4 \mu \mathrm{mol} / \mathrm{mL})$ decreased the initial patulin concentration of $20-1.561 \mu \mathrm{g} / \mathrm{mL}$, and the degradation rate was $92.2 \%$.

\section{Effects of PA at Various Concentrations on Antagonistic Yeast}

As shown in Figure 7 , the growth of $R$. mucilaginosa in combination with $\mathrm{PA}$ at concentrations of $2,4,6$, and $8 \mu \mathrm{mol} / \mathrm{mL}$ showed no significant effect compared with the stand-alone $R$. mucilaginosa treatment. The combined treatment of R. mucilaginosa and PA at the concentration of $10 \mu \mathrm{mol} / \mathrm{mL}$ was most effective.

\section{DISCUSSION}

Natural antioxidants extracted from various plants and fungi have been used recently as novel compounds in the battle against post-harvest development of fungi and the production of mycotoxins (i.e., aflatoxins, ochratoxin A; Ricelli et al., 2002; Reverberi et al., 2005; Zjalic et al., 2006). Recently, phytic acid has been considered to be an antioxidant agent, as it is a potent inhibitor of iron-catalyzed hydroxy radical formation, by chelating the free iron and then blocking the iron coordination site (Graf and Eaton, 1990). In our study,

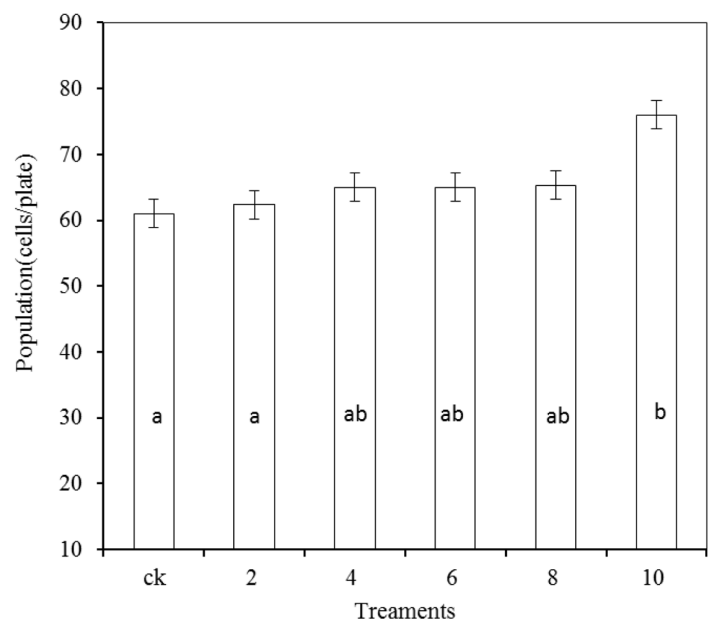

FIGURE 7 | Effects of PA at various concentrations on antagonistic yeast. Treatments are as follows: $\mathrm{CK}=R$. mucilaginosa $\left(1 \times 10^{4} \mathrm{CFU} / \mathrm{mL}\right)$, $(2,4,6,8,10)=R$. mucilaginosa $\left(1 \times 10^{4} \mathrm{CFU} \mathrm{ml^{-1 }}\right)+\mathrm{PA}$ at different concentrations $(2,4,6,8$, and $10 \mu \mathrm{mol} / \mathrm{mL})$. Each value is the mean of two experiments. Bars represent standard deviations. Different letters indicate significant differences $(P<0.05)$ according to the Duncan's multiple range test.

PA at various concentrations, significantly decreased the disease incidence of blue mold decay in apples caused by P. expansum. The results reported here indicate that PA at an appropriate concentration could control postharvest blue mold decay of apples.

The use of biocontrol agents to manage the postharvest decay of fruit has been explored as an alternative to the use of synthetic fungicides (Wilson and Wisniewski, 1989). Our results showed that $R$. mucilaginosa as stand-alone treatment significantly reduced the disease incidence of blue mold decay of apples stored at $20^{\circ} \mathrm{C}$. This suggests that $R$. mucilaginosa has the potential as a biocontrol agent in the control of postharvest blue mold decay of apples. The combination treatment of $R$. mucilaginosa with PA at $4 \mu \mathrm{mol} / \mathrm{mL}$ also significantly reduced the disease incidence of blue mold decay and the lesion diameter of apples at $20^{\circ} \mathrm{C}$, with greater efficacy than $R$. mucilaginosa alone. This indicates that PA at appropriate concentration can enhance the biocontrol efficacy of $R$. mucilaginosa. The mechanism by which PA enhances the biocontrol efficacy of yeast is complex, but it may be attributed to the influence of PA on the antagonist, pathogen, and host. We found that PA used alone, at 2 and $10 \mu \mathrm{mol} / \mathrm{mL}$, had little effect on apple decay. Perhaps PA used as antioxidant, does not enhance the antagonistic yeast at low or high concentrations.

Under in vitro conditions, $\mathrm{PA}$ and $R$. mucilaginosa as stand-alone treatments, inhibited the growth of $P$. expansum on PDA plates, and the efficacy of the combined treatments of $R$. mucilaginosa and PA was better than that of the $R$. mucilaginosa standalone treatment. These results show that PA has the ability to enhance the inhibitory efficacy of $R$. mucilaginosa on the growth of P. expansum, and this may be one of the mechanisms by which PA has the ability to enhance 
the biocontrol efficacy of yeast on postharvest blue mold decay of apples.

Many studies have shown that some yeast antagonists can directly inhibit the production of patulin, while inhibiting P. expansum growth. Coelho et al. (2007) found that an initial patulin content of $223 \mu \mathrm{g}$ in the presence of $158 \mathrm{P}$. ohmeri cells decreased $83 \%$ when incubated at $25^{\circ} \mathrm{C}$ for 2 days, and decreased $>99 \%$ after 5 days incubation. Patulin levels were undetectable after 15 days. The $\mathrm{pH}$ decreased from 4.0 to 3.3 during the 15 days experiment, suggesting that the patulin decrease was an active process and a consequence of yeast metabolism. Our results showed that $R$. mucilaginosa as standalone treatments significantly inhibited patulin production by $P$. expansum in NYDB media. Additionally, $R$. mucilaginosa alone significantly decreased the content of patulin in apple wounds produced by $P$. expansum. These results indicate that $R$. mucilaginosa can control the accumulation of patulin produced by $P$. expansum in apples. Similarly with the biocontrol efficacy of antagonistic yeasts on postharvest diseases, the efficacy of antagonistic yeasts in controlling the accumulation of patulin in apples needs to be enhanced. Tolaini et al. (2010), found that the biocontrol effects of Cryptococcus laurentii, used together with Lentinula edodes, in wounded apples improved the inhibition of $P$. expansum growth and patulin production compared to $C$. laurentii alone, under both experimental and semi-commercial conditions. The relationship between oxidative stress and mycotoxin biosynthesis was further confirmed using antioxidants from Fusarium graminearum and F. culmorum (Reverberi et al., 2010). The metabolic requirement of resistance to a heavily oxidized environment can be a limiting factor for a potential biocontrol agent. Tolaini et al. (2010) described the role of $L$. edodes culture filtrates in reinforcing the competitiveness of the biocontrol agent $C$. laurentii through the enhancement of its antioxidative potential. Similarly, the use of plant-derived antioxidants such as caffeic acid, flavonoids, and phenolic acid from tree nuts reduces Aflatoxigenesis (AF) production by A. flavus by up to $99 \%$, without affecting fungal growth (Mahoney et al., 2010). The antioxidant function of PA is different from that of other antioxidants, as part of the antioxidative effects of PA in lipid-containing model systems can be explained by its radical-scavenging activity. The results from this study show that yeast culture supernatant with $4 \mu \mathrm{mol} / \mathrm{mL} \mathrm{PA}$ exhibited greater inhibition of patulin production by $P$. expansum than either R. mucilaginosa or PA treatments alone, suggesting that PA could enhance the inhibitory activity of $R$. mucilaginosa on the production of patulin. This may be because PA can enhance the inhibitory efficacy of $R$. mucilaginosa on the growth of $P$. expansum. Furthermore, the combination of $R$. mucilaginosa and PA could significantly reduce the patulin content of apples, produced by $P$. expansum. The results obtained suggest that the use of PA $(4 \mu \mathrm{mol} / \mathrm{mL})$ together with $R$. mucilaginosa improves

\section{REFERENCES}

Brankovic, G., Dragicevic, V., Dodig, D., Zoric, M., Knezevic, D., Zilic, S., et al. (2015). Genotype $\mathrm{x}$ environment interaction for antioxidants and phytic acid contents in bread and durum wheat as influenced by climate. the efficiency of the biocontrol activity of the yeast, leading to an almost total inhibition of $P$. expansum growth and patulin production in apples.

In the degradation of patulin by $R$. mucilaginosa, alone or in combination with $\mathrm{PA}$ in vitro, the initial patulin concentration of $20 \mu \mathrm{g} / \mathrm{mL}$ in the presence of $R$. mucilaginosa cells was decreased $92.1 \%$, when incubated at $28^{\circ} \mathrm{C}$ for $24 \mathrm{~h}$. Similarly, the initial patulin concentration of $20 \mu \mathrm{g} / \mathrm{mL}$ in the presence of $R$. mucilaginosa with $4 \mu \mathrm{mol} / \mathrm{mL}$ PA decreased over $92.2 \%$. This shows that PA could not enhance the patulin degradation activity of $R$. mucilaginosa, however, the degradation efficacy of $R$. mucilaginosa or R. mucilaginosa in combination with PA is high, and the patulin was almost completely degraded after $24 \mathrm{~h}$.

\section{CONCLUSION}

Phytic acid at a concentration of $4 \mu \mathrm{mol} / \mathrm{mL}$ significantly enhanced the biocontrol activity of $R$. mucilaginosa against postharvest blue mold decay and the production of patulin in apples. The mode of action may be its direct inhibition on the colony growth of the pathogens. Additionally, both $R$. mucilaginosa and $R$. mucilaginosa in combination with PA degrade patulin in vitro. The effective antagonism of $R$. mucilaginosa versus $P$. expansum hyphal growth suggested that the inhibition of fungal development is a promising alternative for biological control, and consequent potential for low patulin levels in apples. Future research will be aimed at developing the technology to be used in large-scale operations and further investigating the mode of action of PA's enhancement of the biocontrol efficacy of $R$. mucilaginosa on postharvest blue mold decay and patulin production in apples.

\section{AUTHOR CONTRIBUTIONS}

HZ, QY, and XZ conceived and designed the experiments. QY, $\mathrm{XZ}, \mathrm{HZ}$, and $\mathrm{XZ}$ performed the experiments. JQ analyzed the data. HZ, QY, and JQ drafted the manuscript. All authors read and approved the final manuscript.

\section{ACKNOWLEDGMENTS}

This work was supported by the National Natural Science Foundation of China (31271967), the Research Fund for the Doctoral Program of Higher Education of China (20123227110015), the Technology Support Plan of Jiangsu Province (BE2014372), the Technology Support Plan of Zhenjiang (NY2013004), and Graduate Innovative Projects of Jiangsu Province (KYLX_1069).

Chilean J. Agric. Res. 75, 139-146. doi: 10.4067/S0718-58392015000 200001

Buck, J. W. (2004). Combinations of fungicides with phylloplane yeasts for improved control of Botrytis cinerea on geranium seedlings. Phytopathology 94, 196-202. doi: 10.1094/PHYTO.2004.94.2.196 
Burgos-Lujan, L., and Tong, A. Z. (2015). Determination of phytic acid in juices and milks by developing a quick complexometric-titration method. Food Anal. Methods 8, 1836-1841. doi: 10.1007/s12161-014-0075-5

Cao, J., Zhang, H. Y., Yang, Q. Y., and Ren, R. (2013). Efficacy of Pichia caribbica in controlling blue mold rot and patulin degradation in apples. Int. J. Food Microbiol. 162, 167-173. doi: 10.1016/j.ijfoodmicro.2013. 01.007

Castoria, R., De Curtis, F., Lima, G., Caputo, L., Pacifico, S., and De Cicco, V. (2001). Aureobasidium pullulans (LS-30) an antagonist of postharvest pathogens of fruits: study on its modes of action. Postharvest Biol. Technol. 22, 7-17. doi: 10.1016/S0925-5214(00)00186-1

Coelho, A. R., Celli, M. G., Ono, E. Y. S., Wosiacki, G., Hoffmann, F. L., Pagnocca, F. C., et al. (2007). Penicillium expansum versus antagonist yeasts and patulin degradation in vitro. Braz. Arch. Biol. Technol. 50, 725-733. doi: 10.1590/S151689132007000400019

Droby, S. (2006). Improving quality and safety of fresh fruits and vegetables after harvest by the use of biocontrol agents and natural materials. Acta Hortic. 709, 45-52. doi: 10.17660/ActaHortic.2006.709.5

Du, Y., Dou, S., and Wu, S. (2012). Efficacy of phytic acid as an inhibitor of enzymatic and non-enzymatic browning in apple juice. Food Chem. 135, 580-582. doi: 10.1016/j.foodchem.2012.04.131

El-Ghaouth, A., Smilanick, J. L., Wisniewski, M., and Wilson, C. L. (2000). Improved control of apple and citrus fruit decay with a combination of Candida saitoana and 2-deoxy-D-glucose. Plant Dis. 84, 249-253. doi: 10.1094/PDIS.2000.84.3.249

Graf, E., and Eaton, J. W. (1990). Antioxidant functions of phytic acid. Free Radic. Biol. Med. 8, 61-69. doi: 10.1016/0891-5849(90)90146-A

Gupta, R. K., Mensah-Darkwa, K., and Kumar, D. (2013). Effect of post heat treatment on corrosion resistance of phytic acid conversion coated magnesium. J. Mater. Sci. Technol. 29, 180-186. doi: 10.1016/j.jmst.2012.12.014

Janisiewicz, W. (1994). Enhancement of biocontrol of blue mold with the nutrient analog 2-deoxy-D-glucose on apples and pears. Appl. Environ. Microbiol. 60, 2671-2676.

Janisiewicz, W., Tworkoski, T., and Sharer, C. (2000). Characterizing the mechanism of biological control of postharvest diseases on fruits with a simple method to study competition for nutrients. Phytopathology 90, 1196-1200. doi: 10.1094/PHYTO.2000.90.11.1196

Janisiewicz, W. J., and Korsten, L. (2002). Biological control of postharvest diseases of fruits. Annu. Rev. Phytopathol. 40, 411-441. doi: 10.1146/annurev.phyto.40.120401.130158

Li, R. P., Zhang, H. Y., Liu, W. M., and Zheng, X. D. (2011). Biocontrol of postharvest gray and blue mold decay of apples with Rhodotorula mucilaginosa and possible mechanisms of action. Int. J. Food Microbiol. 146, 151-156. doi: 10.1016/j.ijfoodmicro.2011.02.015

Mahoney, N., Molyneux, R., Kim, J. H., Campbell, B., Waiss, A., and Hagerman, A. (2010). Aflatoxigenesis induced in Aspergillus flavus by oxidative stress and reduction by phenolic antioxidants from tree nuts. World Mycotoxin J. 3, 49-57. doi: 10.3920/WMJ2009.1185

Paster, N., Huppert, D., and Barkai-Golan, R. (1995). Production of patulin by different strains of Penicillium expansum in pear and apple cultivars stored at different temperatures and modified atmospheres. Food Addit. Contam. 12, 51-58. doi: 10.1080/02652039509374278

Reverberi, M., Fabbri, A. A., Zjalic, S., Ricelli, A., Punelli, F., and Fanelli, C. (2005). Antioxidant enzymes stimulation in Aspergillus parasiticus by Lentinula edodes inhibits aflatoxin production. Appl. Microbiol. Biotechnol. 69, 207-215. doi: 10.1007/s00253-005-1979-1

Reverberi, M., Punelli, F., Scarpari, M., Camera, E., Zjalic, S., Ricelli, A., et al. (2010). Lipoperoxidation affects ochratoxin A biosynthesis in Aspergillus ochraceus and its interaction with wheat seeds. Appl. Microbiol. Biotechnol. 85, 1935-1946. doi: 10.1007/s00253-009-2220-4

Ricelli, A., Fabbri, A. A., Trionfetti-Nisini, P., Reverberi, M., Zjalic, S., and Fanelli, C. (2002). Inhibiting effect of different edible and medicinal mushrooms on the growth of two ochratoxigenic microfungi. Int. J. Med. Mushrooms 4:8. doi: 10.1615/IntJMedMushr.v4.i2.110

Riteni, A. (2003). Patulin in Italian commercial apple products. J. Agric. Food Chem. 51, 6086-6090. doi: 10.1021/jf034523c

Shamsuddin, A. M. (2002). Anti-cancer function of phytic acid. Int. J. Food Sci. Technol. 37, 769-782. doi: 10.1046/j.1365-2621.2002.00620.x

Sommer, N. F., Buchanan, J. R., and Fortlage, R. J. (1974). Production of patulin by Penicillium expansum. Appl. Environ. Microbiol. 28, 589-593.

Sugar, D., and Spotts, R. A. (1999). Control of postharvest decay in pear by four laboratory-grown yeasts and two registered biocontrol products. Plant Dis. 83, 155-158. doi: 10.1094/PDIS.1999.83.2.155

Tolaini, V., Zjalic, S., Reverberi, M., Fanelli, C., Fabbri, A. A., Del Fiore, A., et al. (2010). Lentinula edodes enhances the biocontrol activity of Cryptococcus laurentii against Penicillium expansum contamination and patulin production in apple fruits. Int. J. Food Microbiol. 138, 243-249. doi: 10.1016/j.ijfoodmicro.2010.01.044

Usall, J., Teixidó, N., Torres, R., Ochoa de Eribe, X., and Viñas, I. (2001). Pilot tests of Candida sake (CPA-1) applications to control postharvest blue mold on apple fruit. Postharvest Biol. Technol. 21, 147-156. doi: 10.1016/S0925-5214(00) 131-139

Wilson, C. L., and Wisniewski, M. E. (1989). Biological control of postharvest diseases of fruits and vegetables: an emerging technology. Annu. Rev. Phytopathol. 27, 425-441. doi: 10.1146/annurev.py.27.090189.002233

Wu, R. N., Dang, Y. L., Niu, L., and Hu, H. (2008). Application of matrix solid-phase dispersion-HPLC method to determine patulin in apple and apple juice concentrate. J. Food Compost. Anal. 21, 582-586. doi: 10.1016/j.jfca.2008. 05.010

Zhang, H. Y., Yang, Q. Y., Lin, H. T., Ren, X. F., Zhao, L. N., and Hou, J. S. (2013). Phytic acid enhances biocontrol efficacy of Rhodotorula mucilaginosa against postharvest gray mold spoilage and natural spoilage of strawberries. LWT-Food Sci. Technol. 52, 110-115. doi: 10.1016/j.lwt.2012.01.027

Zjalic, S., Reverberi, M., Ricelli, A., Mario Granito, V., Fanelli, C., and Adele Fabbri, A. (2006). Trametes versicolor: a possible tool for aflatoxin control. Int. J. Food Microbiol. 107, 243-249. doi: 10.1016/j.ijfoodmicro.2005. 10.003

Conflict of Interest Statement: The authors declare that the research was conducted in the absence of any commercial or financial relationships that could be construed as a potential conflict of interest.

Copyright (c) 2015 Yang, Zhang, Zhang, Zheng and Qian. This is an open-access article distributed under the terms of the Creative Commons Attribution License (CC BY). The use, distribution or reproduction in other forums is permitted, provided the original author(s) or licensor are credited and that the original publication in this journal is cited, in accordance with accepted academic practice. No use, distribution or reproduction is permitted which does not comply with these terms. 